\title{
LETTER
}

\section{The 372 T/C genetic polymorphism of TIMP-1 as a biomarker of mortality in patients with sepsis}

\author{
Leonardo Lorente ${ }^{1 *}$ and Maria M Martín ${ }^{2}$
}

\section{See related commentary by Behnes et al, http.//ccforum.com/content/17/4/170 and related research by Lorente et al, http//ccforum.com/content/17/3/R94}

In the previous issue of Critical Care, Behnes and colleagues [1] provide an interesting commentary on our study showing that septic patients with the T-allele in $372 \mathrm{~T} / \mathrm{C}$ (rs4898) genetic polymorphism of the tissue inhibitor of metalloproteinase-1 (TIMP-1) had higher mortality and higher TIMP-1 serum levels than those without it [2].

As the authors state in their commentary, our study had some limitations. One limitation was the relatively small sample size to establish prognostic implications by only one single-nucleotide polymorphism (SNP) challenge. However, the sample size was large enough to find an association between polymorphism and survival.

Another limitation was that we tested only the rs4898 SNP, a tag SNP, for the region of interest. However, it may be that this SNP, which is in strong linkage disequilibrium with other TIMP-1 polymorphisms, is linked to other SNPs associated with the same effect.

Another possibility is that this association represents only an epiphenomenon since, in our study, a causeeffect relationship between polymorphism and mortality was not established. However, we found that patients with the T-allele had higher TIMP-1 serum levels and that patients with higher TIMP-1 circulating levels showed higher mortality [3,4]. Besides, we found a positive association between TIMP-1 and plasminogen activator inhibitor-1 circulating levels, previously found in myocardial infarction patients [5], probably suggesting a prothrombotic state. In conclusion, we think that the determinations of $372 \mathrm{~T} / \mathrm{C}$ genetic polymorphism and circulating levels of TIMP-1 could be used as mortality biomarkers in patients with sepsis.

\footnotetext{
* Correspondence: lorentemartin@msn.com

${ }^{1}$ Intensive Care Unit, Hospital Universitario de Canarias, Ofra s/n La Laguna, 38320, Santa Cruz de Tenerife, Spain

Full list of author information is available at the end of the article
}

\section{Abbreviations}

SNP: Single-nucleotide polymorphism; TIMP: Tissue inhibitor of matrix metalloproteinase.

\section{Competing interests}

The authors declare that they have no competing interests.

\section{Authors' contributions}

$\mathrm{LL}$ drafted the manuscript and MMM reviewed it. Both authors read and approved the final manuscript.

\section{Acknowledgments}

This study was supported, in part, by grants (FIS/PI-10-1572, I3SNS-INT-11063, and I3SNS-INT-12-087) from Instituto de Salud Carlos III (Madrid, Spain).

\section{Author details}

${ }^{1}$ Intensive Care Unit, Hospital Universitario de Canarias, Ofra s/n La Laguna, 38320, Santa Cruz de Tenerife, Spain. ${ }^{2}$ Intensive Care Unit, Hospital Universitario Nuestra Señora Candelaria, Carretera Rosario s/n, 38010, Santa Cruz de Tenerife, Spain.

Published: 03 Oct 2013

\section{References}

1. Behnes M, Bertsch T, Hoffmann: TIMP-1 gene polymorphism: are genetics able to predict outcome of septic patients? Crit Care 2013, 17:170.

2. Lorente L, Martín MM, Plasencia F, Solé-Violán J, Blanquer J, Labarta L, Díaz C, Borreguero-León JM, Jiménez A, Páramo JA, Orbe J, Rodríguez JA, Salido E: The 372 T/C genetic polymorphism of TIMP-1 is associated with serum levels of TIMP-1 and survival in patients with severe sepsis. Crit Care 2013, 17:R94.

3. Hoffmann U, Bertsch T, Dvortsak E, Liebetrau C, Lang S, Liebe V, Huhle G, Borggrefe M, Brueckmann M: Matrix-metalloproteinases and their inhibitors are elevated in severe sepsis: prognostic value of TIMP-1 in severe sepsis. Scand J Infect Dis 2006, 38:867-872.

4. Lorente L, Martín MM, Labarta L, Díaz C, Solé-Violán J, Blanquer J, Orbe J, Rodríguez JA, Jiménez A, Borreguero-León JM, Belmonte F, Medina JC, Llimiñana MC, Ferrer-Agüero JM, Ferreres J, Mora ML, Lubillo S, Sánchez M, Barrios Y, Sierra A, Páramo JA: Matrix metalloproteinase-9, -10, and tissue inhibitor of matrix metalloproteinases-1 blood levels as biomarkers of severity and mortality in sepsis. Crit Care 2009, 13:R158.

5. Cavusoglu E, Ruwende C, Chopra V, Yanamadala S, Eng C, Clark LT, Pinsky DJ, Marmur JD: Tissue inhibitor of metalloproteinase-1 (TIMP-1) is an independent predictor of all-cause mortality, cardiac mortality, and myocardial infarction. Am Heart J 2006, 151:1101. e1-8.

\section{$10.1186 / \mathrm{cc} 13037$}

Cite this article as: Lorente and Martín: The 372 T/C genetic polymorphism of TIMP-1 as a biomarker of mortality in patients with sepsis. Critical Care 2013, 17:456 